\title{
AKUPRESUR TERHADAP PRODUKSI ASI PADA IBU POST PARTUM
}

\author{
Nur Djanah, Wafi Nur Muslihatun
}

Jurusan Kebidanan Poltekkes Kemenkes Yogyakarta

e-mail: nurdjanah.fendi@gmail.com

\begin{abstract}
Background: Breast feeding is one important pillars for babies because breast milk is the best nutrition for newborn up to 6 months old. Riskesdas data in 2013 showed that only $34.5 \%$ baby in Indonesia who are breastfeed exclusively, the meaning that there are stil about $2 / 3$ of babies in Indonesia who less likely to get breast milk. The lack of production of breast milk is one of the obstacles in breast feeding exclusively. Acupressure is one of the non-pharmacological approach, to improve the production of breast milk. Purpose: To describes the effect of acupressure to improve the production of breast milk with the indicators were baby weigh and the frequency of urinary. Methods: The design used was quasy experiment with pre and post test design. Total sample is 30. The sampling techniques with accidental sampling. Data was analyzed with Friedman test and followed by Willcoxon test. The independent variable was postpartum mother and dependent variablle was the production of milk with the indicators were baby weight and the frequency of urinary. Instrument was using questionaire and observation sheet Results: The average birth weight was 3195 gram and the average of urinary was 6 times on the first day of newborn. Both indicators above was increased during the 2 and 4 weeks of born. The result of bivariat analysis showed there are the difference of weight with $p$ value: 0,001 and the difference of frequency of urinary with p value: 0,001. Summary: That accupresure affects on breats milk production with the indicator of the baby wight and frequency of urinary.
\end{abstract}

Keywords: Accupresure, Infant Weight, Exclusive Breastfeeding

\section{PENDAHULUAN}

Mendapatkan Air Susu Ibu (ASI) merupakan hak setiap bayi dan yang terbaik adalah dengan diberikan secara eksklusif yaitu sejak bayi lahir sampai dengan usia 6 (enam) bulan tanpa ditambahkan dan/atau diganti dengan makanan atau minuman lain. ASI sangat penting bagi kehidupan setiap bayi, bahkan pemberian ASI eksklusif merupakan salah satu cara untuk mencegah terjadinya kematian pada bayi dan balita. Beberapa penelitian membuktikan keterkaitan antara ASI eksklusif dengan risiko kematian pada bayi dan balita adalah penelitian dari WHO yang dilakukan di 6 (enam) negara berkembang dan menyimpulkan bahwa risiko kematian bayi dengan usia antara 9-12 bulan meningkat $40 \%$ apabila bayi tersebut tidak mendapatkan ASI. Penelitian lainnya adalah yang dilakukan Jones Lancet dan Karen Edmond yang mendapatkan bahwa dengan menyusui eksklusif selama 6 (enam) bulan dan tetap diberi ASI sampai 11 bulan saja serta pemberian makanan pendamping ASI pada usia enam bulan dapat menurunkan kematian balita sebanyak 13 $\%{ }^{1,2}$

ASI eksklusif sangat besar manfaatnya bagi kelangsungan hidup setiap bayi tetapi secara nasional cakupan ASI eklusif di Indonesia masih rendah. Data Riskesdas 2013 menunjukkan bahwa baru $34.5 \%$ bayi di Indonesia yang mendapat ASI eklusif, artinya masih ada sekitar 2/3 bayi di Indonesia yang kurang mendapatkan ASI. Provinsi Daerah Istimewa Yogyakarta juga masih belum maksimal dalam pencapaian target nasional pemberian ASI eksklusif. Berdasarkan profil kesehatan Yogyakarta dapat dilihat bahwa cakupan ASI eksklusif pada tahun 2008 menjadi $39,9 \%$ yang menjadi menurun pada tahun 2009 hingga $34,56 \%$. Angka tersebut kembali meningkat pada tahun 2010 dan 2011 menjadi sebesar $40,03 \%$ dan $49,5 \%$ tetapi kembali menurun menjadi $48 \%$ pada tahun $2012.3,4$

Pemerintah terus berupaya untuk meningkatkan angka cakupan ASI eksklusif bagi anak-anak Indonesia dan ini dibuktikan dengan diterbitkannya Peraturan Pemerintah nomor 33 tahun 2012 tentang pemberian Air Susu Ibu eksklusif untuk dapat melaksanakan ketentuan Undang-Undang nomor 36 tahun 2009 tentang kesehatan. Peraturan Pemerintah ini bertujuan untuk menjamin terpenuhinya hak bayi untuk mendapatkan ASI eksklusif. ${ }^{5}$

Sesuai dengan fenomena yang telah dijelaskan di atas dan berdasarkan hasil 
pengamatan peneliti, ibu-ibu yang bersalin di Klinik Mujahidah Bantul, khususnya budaya Jawa, masih banyak dijumpai para ibu melakukan perawatan nifas berdasarkan budaya dan tradisinya, termasuk dalam hal menyususi, namun pada sebagian ibu mungkin saja terjadi kesulitan pengeluaran ASI karena lebih banyak ibu terpengaruh mitos sehingga ibu tidak yakin bisa memberikan ASI pada bayinya. Perasaan ibu yang tidak yakin bisa memberikan ASI pada bayinya akan menyebabkan penurunan hormon oksitosin sehingga ASI tidak dapat keluar segera setelah melahirkan dan akhirnya ibu memutuskan untuk memberikan susu formula. Salah satu upaya yang bisa dilakukan untuk merangsang hormon prolaktin dan oksitosin pada ibu setelah melahirkan adalah dengan melakukan akupresur. $^{6-8}$

Akupresur adalah teknik pengobatan nonfarmakologi yang berkaitan erat dengan akupunktur, dengan melakukan tekanan pada titik-titik tertentu dalam tubuh. Akupresur sebagai seni dan ilmu penyembuhan berlandaskan pada teori keseimbangan yin dan yang. Yin dan Yang adalah dua aspek yang saling mendasari, saling mempengaruhi, tidak mutlak dan keduanya saling bertentangan tetapi membentuk suatu kesatuan yang utuh dalam suatu keseimbangan yang harmonis dan dinamis. Akupresur dapat menghasilkan efek melalui beberapa mekanisme yang berbeda. Titik akupresur memiliki sifat listrik yang ketika dirangsang dapat mengubah tingkat neurotransmiter kimia tubuh. Akupresur diyakini untuk melepaskan rasa sakit dan ketegangan otot, meningkatkan sirkulasi dan pelepasan endorfin. ${ }^{9-}$ 11

Akupresur merupakan tindakan non invasif, mudah dilakukan, memiliki efek samping yang minimal, dan mendekatkan hubungan terapeutik antara klien dan bidan. Studi yang dilakukan oleh Savabi et al menyimpulkan bahwa akupresur merupakan metode efektif dalam meningkatkan volume air susu ibu menyusui. ${ }^{12}$

\section{METODOLOGI PENELITIAN}

Jenis penelitian adalah quase eksperimen dengan bentuk rancangan pre and post test design. ${ }^{13}$

$$
\begin{array}{llll}
\mathrm{O}_{1} & \mathrm{X} & \mathrm{O}_{2} & \mathrm{O}_{3}
\end{array}
$$

\section{Gambar 1. Desain Penelitian}

Penelitian dilaksanakan selama periode Mei sampai Agustus 2016. Tempat penelitian di Klinik Mujahidah Bantul. Sampel yang dipilih dalam penelitian adalah ibu post partum yang memenuhi kriteria inklusi dan tidak ada kriteria eksklusi. melahirkan secara normal dengan umur kehamilan aterm,berat bayi lahir 2500 - 4000 gram, ibu dan bayi sehat yang ditentukan dari pemeriksaan dokter atau bidan jaga di Klinik Mujahidah, ibu bersedia memberi ASI secara eksklusif, serta bersedia menjadi responden. Kriteria eksklusi adalah bayi diberi minum selain ASI, terdapat kontra indikasi dilakukan akupresur yaitu yaitu: kulit yang terluka, fraktur, bengkak dan myalgia pada lokasi acupoint. Pengambilan sampel menggunakan accidental sampling ${ }^{14}$. Jumlah sampel dalam penelitian ini adalah 30 responden.

Variabel terikat yaitu produksi ASI dengan indikator berat badan bayi dan frekuensi bayi BAK. Variabel bebas adalah akupresur pada acupoint SI 1, LI4, dan ST 18. Pengukuran berat badan bayi menggunakan lembar observasi dengan menggunakan alat bantu timbangan bayi, sedangkan frekuensi bayi BAK menggunakan chekslist.

Penelitian ini sudah mendapat persetujuan dari Komite Etik Penelitian Poltekkes Kemenkes Yogyakarta dalam upaya melindungi hak asasi dan kesejahteraan responden yang dibuktikan dalam bentuk Surat Keterangan Kelayakan Etik / Ethical Clearance dengan nomor LB.01.01/KE/XXIV/166/2016.

Data diolah menggunakan komputer melalui 4 tahap yaitu editing, coding, prosessing dan cleaning. Analisis data menggunakan software SPSS for Windows versi 18.0 yang meliputi analisis univariat dan bivariat dengan mengunakan uji Friedman dan dilanjutkan analisis Post Hoc dengan uji Wilcoxon. ${ }^{13}$ 


\section{HASIL DAN PEMBAHASAN}

Analisis univariat

Karakteristik responden yang diperhatikan dalam ppenellitian ini adalah riwayat minum jamu untuk memperlancar ASI, paritas dan umur ibu.

Tabel 1. Distribusi responden berdasarkan riwayat minum jamu untuk memperlancar

\begin{tabular}{llll}
\multicolumn{5}{c}{ ASI } \\
\hline NO & Variabel & $\mathrm{f}$ & $(\%)$ \\
\hline 1 & Riwayat minum & \\
& jamu $\quad$ untuk & \\
& memperlancar ASI & & \\
& Minum jamu & 21 & 70 \\
& Tidak minum jamu & 9 & 30 \\
\hline
\end{tabular}

Tabel 1 menunjukkan sebagian besar $(70 \%)$ responden pernah minum jamu untuk memperlancar ASI. Adanya makanan atau ramuan yang dipercaya dapat meningkatkan produksi ASI (Lactogogue) seperti daun katu, jagung atau kacang-kacangan dapat menambah kepercayaan ibu sehingga dapat membantu refleks oksitosin. ${ }^{6}$ Studi yang dilakukan Dewi menyimpulkan bahwa faktor makanan mempunyai pengaruh yang signifikan terhadap produksi ASI. ${ }^{15}$

Tabel 2. Distribusi responden berdasarkan paritas dan umur ibu (tahun)

\begin{tabular}{lllll}
\hline No & Variabel & $\begin{array}{c}\text { Median } \\
\text { (Minimum- } \\
\text { Maksimum) }\end{array}$ & $\begin{array}{c}\text { Mean } \\
\text { SD }\end{array}$ \\
\hline 1 & Paritas & $1(0-3)$ & $1 \pm 0,89$ \\
\hline 2 & Umur ibu & $29(20-37)$ & 28,5 & \pm \\
& & & 4,98 & \\
\hline
\end{tabular}

Tabel 2 menunjukkan bahwa rata-rata paritas responden adalah 1 dengan paritas minimum 0 dan maksimal 3,sedangkan rata-rata umur ibu 28,5 tahun dengan umur minimal 20 tahun dan maksimal 37 tahun. Studi yang dilakukan oleh Enok tentang faktor-faktor yang berhubungan dengan produksi ASI menyimpulkan bahwa umur ibu dan paritas ibu tidak berhubungan dengan produksi ASI. ${ }^{16}$
Analisis bivariat

Tabel 3. Perbandingan skor produksi ASI dengan indikator berat badan bayi (gram) dan frekuensi bayi BAK sebelum dan sesudah perlakuan akupresur

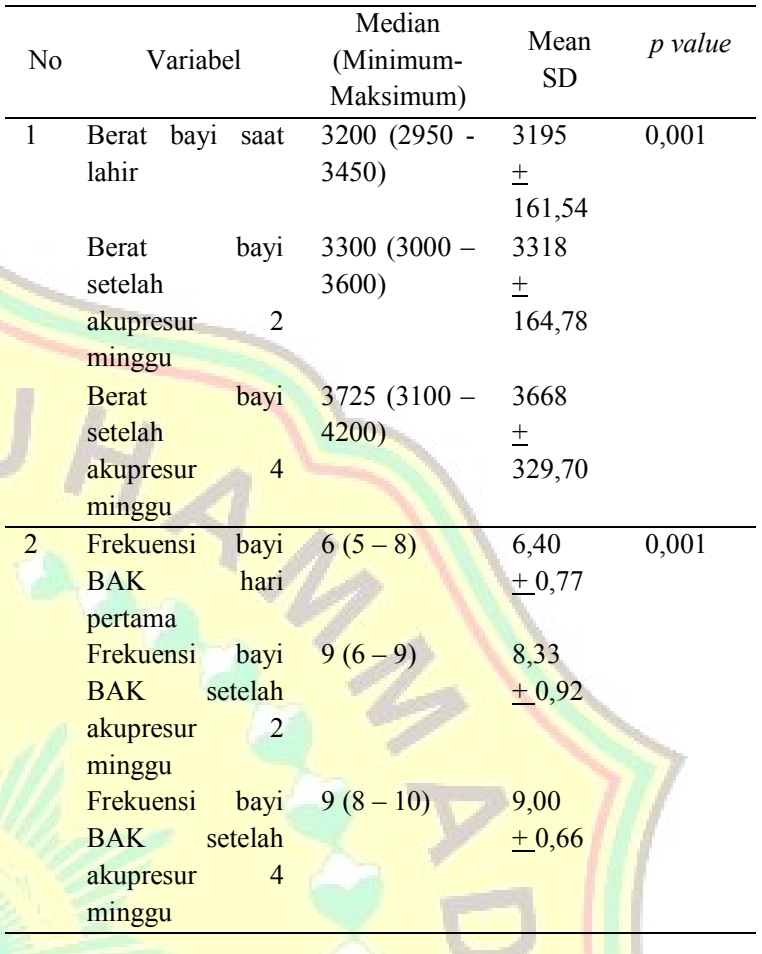

Tabel 3 menunjukkan bahwa rata-rata berat bayi saat lahir adalah 3195 gram dengan nilai minimal 2950 gram dan nilai maksimal 3450 gram. Setelah dilakukan akupresur, rata-rata berat bayi pada umur dua minggu adalah 3318 gram dengan berat bayi minimal 3000 gram dan maksimal 3600 gram. Pada umur 4 minggu ratarata berat bayi adalah 3668 gram dengan berat bayi minimal 3100 gram dan maksimal 4200 gram.

Rata-rata frekuensi bayi BAK dalam hari pertama adalah 6 kali dengan frekuensi minimal 5 kali dan maksimal 8 kali. Setelah dilakukan akupresur, rata-rata frekuensi bayi BAK pada umur dua minggu adalah 8 kali dengan frekuensi minimal 6 kali dan maksimal 9 kali. Pada umur empat minggu rata-rata frekuensi bayi BAK adalah 9 kali dengan frekuensi minimal 8 kali dan maksimal 10 kali.

Hasil analisis dengan uji Friedman dan dilanjutkan uji Post Hoc Wilcoxon menunjukkan perbedaan rata-rata berat bayi saat lahir dan sesudah dua minggu pasca akupresur, perbedaan 
rata-rata berat bayi saat lahir dan sesudah 4 minggu pasca akupresur, serta perbedaan ratarata berat bayi sesudah dua minggu dan setelah empat minggu pasca akupresur yang secara statistik bermakna dengan $p$ value $<0,05$.

Hasil analisis juga menunjukkan perbedaan frekuensi bayi BAK pada hari pertama dan sesudah dua minggu pasca akupresur, perbedaan frekuensi bayi BAK pada hari pertama dan sesudah empat minggu pasca akupresur, serta perbedaan frekuensi bayi BAK sesudah dua minggu dan setelah empat minggu pasca akupresur yang secara statistik bermakna dengan $\mathrm{p}$ value $<0,05$.

Hasil penelitian menunjukkan bahwa terjadi peningkatan berat badan yang signifikan dengan $\mathrm{p}$ value 0,001 , hal ini menunjukkan adanya perbedaan berat badan bayi pada dua kali pengukuran yaitu pada umur dua dan empat minggu. Berat badan bayi merupakan salah satu indikator dari kelancaran ASI. Pada bayi yang mendapatkan ASI eksklusif penurunan berat badan hanya terjadi $3-5 \%$ pada hari ketiga dan berat badan pada minggu kedua minimal sama atau bahkan mengalami kenaikan. ${ }^{17}$

Hasil penelitian menunjukkan bahwa frekuensi BAK bayi pada hari pertama rata-rata 6 kali, pada minggu kedua 8 kali, dan pada minggu keempat rata-rata 9 kali dalam 24 jam. Hal ini menunjukkan bahwa bayi akan sering kencing ketika bayi mendapatkan cukup nutrisi. Frekuensi BAK merupakan indikator kedua, bahwa bila bayi cukup mendapatkan ASI akan buang air antara enam sampai delapan kali dalam 24 jam dengan warna jernih kekuningan. ${ }^{18}$

Hasil penelitian mendukung hipotesis penelitian bahwa ada pengaruh akupresur terhadap produksi ASI dengan indikator berat badan bayi dan frekuensi bayi BAK. Temuan dalam penelitian ini sejalan dengan hasil studi yang dilakukan oleh Mitra dkk bahwa akupresur efektif dalam meningkatkan volume ASI. ${ }^{12}$

Keterbatasan dalam penelitian ini adalah dapat terjadi bias pengukuran karena variabilitas kemampuan pengumpul data dalam melakukan akupresur, meskipun sudah ada panduan pelaksaan akupresur dan telah dilakukan pelatihan pelaksanaan akupresur sebelumnya.
Tidak dikendalikannya variabel emosi dan sikap ibu, sehingga tidak menutup kemungkinan perbedaan hasil setelah perlakuan dipengaruhi oleh faktor emosi dan sikap ibu.

\section{KESIMPULAN}

Berdasarkan hasil penelitian dan pembahasan maka dapat disimpulkan bahwa ada pengaruh akupresur terhadap produksi ASI pada ibu postpartum di klinik Mujahidah Bantul dengan indikator berat badan bayi dan frekuensi bayi BAK. Akupresur dapat digunakan sebagai alternatif dalam upaya peningkatan produksi ASI selama masa nifas. Perlunya penelitian lanjutan dengan mengendalikan variabel emosi dan sikap ibu.

\section{DAFTAR PUSTAKA}

Roesli, Utami. 2008. Inisiasi Menyusu Dini plus ASI Eksklusif. Cet-1. Jakarta: Pustaka Bunda.

WHO, 2003. Community-based Strategies for Breastfeeding Promotion and Support in Developing Countries. Geneva.

Depkes RI. 2013. Laporan Hasil Riset Kesehatan Dasar Indonesia. Jakarta: Depkes RI

Dinas Kesehatan Prov. DIY, 2013, Profil Kesehatan Yogyakarta 2008-2012.

Peraturan Pemerintah No. 33 Tahun 2012 Tentang Pemberian ASI Eksklusif.

Sujiyatini,Nurdjanah,Ana K,2010. Catatan Kuliah Asuhan Ibu Nifas. Cet-1. Yogyakarta: Cyrillus Publisher

Sumber Waras. Pedoman Praktis dan Metode Umum Akupresur. Yogyakarta.2013

Mehta,2007 The science and benefits of acupresurre therapy dari http://www.associatedcontent.com/article/ $284965 /$ the Science-and benefits of acupressure

Radyanto IWH. Akupresur Untuk Berbagai Penyakit. Andi Offset.Yogyakarta.2012.

Acupressure, Shiatsu, Tuina. Natural Standard Professional Monograph, Copyright (C) 2013 (updated 2013 June 15) Avaible from:

http://www.naturalstandard.com/demo/ demo-pro-shiatsu.asp\#synonyms 
Koosnadi S. Buku Ajar Biofisika Akupunktur Dalam Konsep Kedokteran Energi. Salemba Medika.Jakarta.2012.

Mitra Savabi Esfahani, Shohreh Berenji-Sooghe, and Soheila Ehsanpour. 2015. Effect of acupressure on milk volume of breastfeeding mothers referring to selected health care centers in Tehran. Iran J Nurs Midwifery Res. 2015 Jan-Feb; 20(1): 7-11. M.Sopiyudin D.Statistik Untuk Kedokteran dan Kesehatan.Salemba Medika.Jakarta.2011.

M.Sopiyudin D. Besar Sampel dan Cara Pengambilan Sampel.Salemba Medika.Jakarta.2010.
Dewi P, Sri N. Faktor- Faktor Yang Mempengaruhi Produksi ASI Pada Ibu Nifas.2012

Enok N.Faktor-Faktor Yng Berhubungan Dengan Produksi ASI Pada Ibu Pasca SC Diwilayah Kota Dan Kabupaten Tasikmalaya (Tesis).2010.

Bobak, LM, Lowdermilk,DL，\& Jensen,M.D (2005). Buku Ajar Keperawatan Maternitas (Maria A Wijayanti \& Peter Anugrah,Penerjemah), Jakarta;EGC

Soetjiningsih,2014. Tumbuh Kembang Anak Edisi 2. Jakarta: EGC

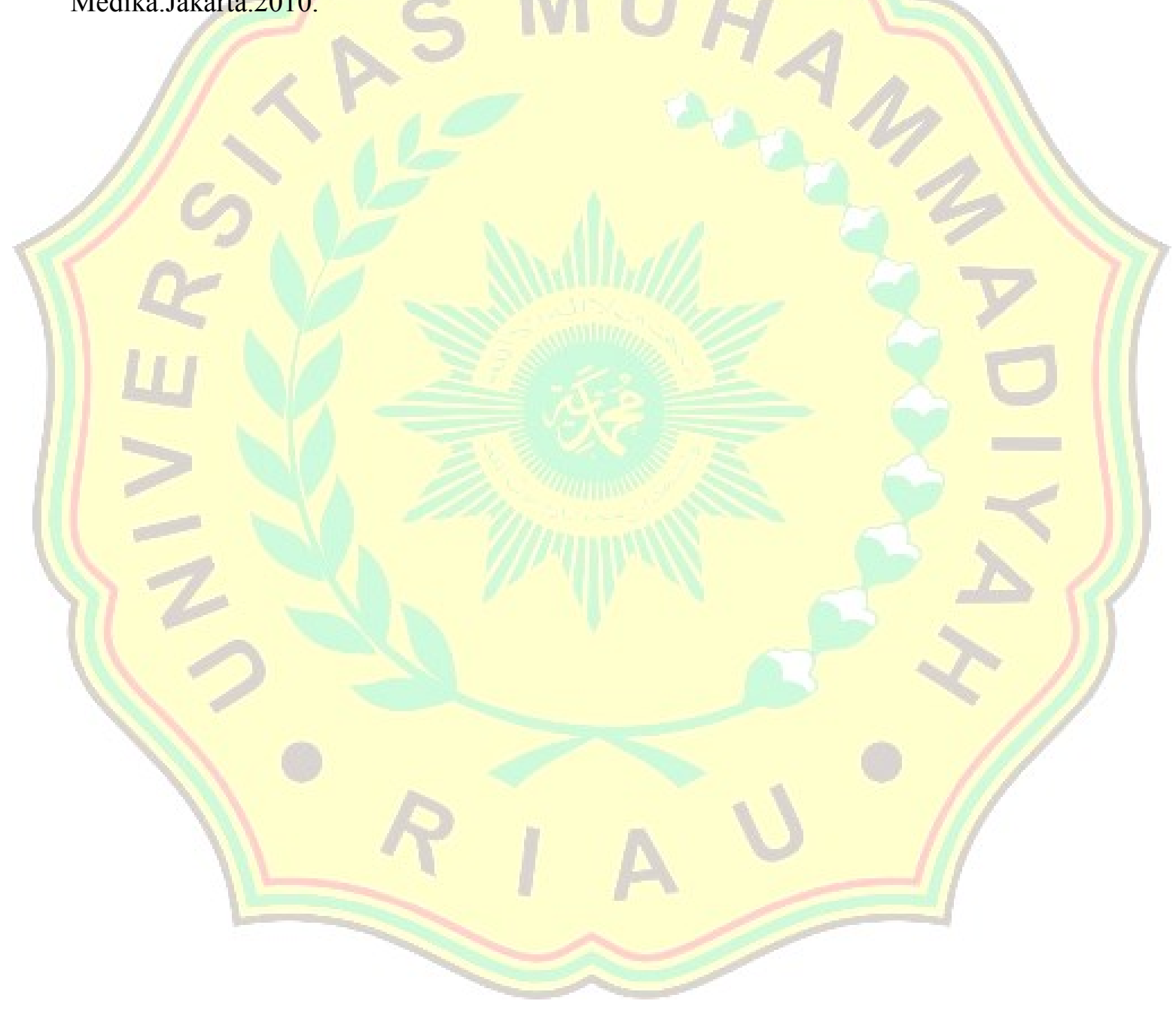

